\title{
PENGEMBANGAN BAHAN AJAR BERBASIS PENDIDIKAN MATEMATIKA REALISTIK (PMR) PADA MATERI PROGRAM LINEAR
}

\author{
Sri Mayani ${ }^{1)}$, Swaditya Rizki ${ }^{2}$ \\ 1), 2) Pendidikan Matematika FKIP Universitas Muhammadiyah Metro \\ srimayani77@yahoo.co.id ${ }^{1)}$, swaditya.rizki@gmail.com ${ }^{2)}$
}

\begin{abstract}
The products developed are based teaching materials realistic mathematics education. Purpose of this research is (1) Develop products in the form of teaching materials based on realistic mathematics education they deserve. (2) To determine the effectiveness of teaching materials based on realistic mathematics education on a linear program material. Development steps used is seeking potential and problems, collect data, product design, design validation, design revisions, product testing, product revision, utility testing, product revision, and mass production. The study population were students of class X Vocational High School Muhammadiyah 3 Metro and sample are learners class X1 (experimental group) and learners class X2 (control group). Validation results showed a very decent category with the percentage of $80,72 \%$. The test results showed a small group categorized by the percentage of $69 \%$. The test results showed a large group instructional materials primarily to the percentage of $77 \%$ feasible and effective in its use based on the average learning outcomes of students in large groups. Based on this, it can be concluded that (1) developed teaching materials eligible for use in learning. (2) The teaching materials are effective in learning.
\end{abstract}

Keywords: research and development $(R \& D)$, teaching materials, realistic mathematics education.

\section{PENDAHULUAN}

Pembelajaran matematika saat ini belum menunjukkan hasil yang memuaskan, hal ini tampak pada hasil belajar peserta didik yang masih berada di bawah kriteria ketuntasan minimal (KKM). Kegiatan pembelajaran yang dianggap paling aman untuk sekarang ini yaitu KBM yang mengikuti buku dari berbagai terbitan dengan pendekatan konvensional dan metode ceramah. Padahal dalam pencapaian kompetensi yang tertuang pada standar kompetensi (SK) dan kompetensi dasar (KD) memerlukan pembelajaran dengan 
pendekatan dan metode aktif dan lebih nyata, sehingga peserta didik dapat membentuk pengetahuan barunya dengan kemampuan sendiri.

Sumber belajar merupakan salah satu bagian terpenting dalam RPP, oleh karena itu guru diharapkan mengembangkan bahan ajar sebagai salah satu sumber belajar. Sumber yang diharapkan adalah sumber belajar yang sesuai dengan tujuan pembelajaran. Berdasarkan hal tersebut guru hendaknya membuat sendiri bahan ajar yang tentunya dapat lebih memudahkan peserta didik dalam memahami materi yang diajarkan.
Berdasarkan prasurvei yang dilakukan di SMK Muhammadiyah 3 Metro pada tanggal 5 November 2015 didapat data hasil belajar peserta didik belum memuaskan. Data diperoleh dari hasil nilai ulangan harian yang menunjukkan dari 40 peserta didik yang mengikuti ulangan harian belum ada yang memenuhi kriteria ketuntasan yang berlaku di sekolah. Hasil belajar ini menyatakan bahwa $100 \%$ peserta didik belum mencapai KKM yaitu $\geq 76$. Adapun data hasil belajar matematika peserta didik kelas $\mathrm{X}$ Farmasi 1 dapat dilihat pada Tabel 1 berikut:

Tabel 1. Data hasil belajar matematika nilai ulangan harian pelajaran matematika peserta didik kelas X Farmasi 1 SMK Muhammadiyah 3 Metro T.P 2015/2016

\begin{tabular}{|c|c|c|c|c|}
\hline No & Nilai & Kriteria & Jumlah & $\%$ \\
\hline 1 & $\geq 76$ & Tuntas belajar & 0 & 0 \\
\hline 2 & $<76$ & Belum tuntas belajar & 39 & $100 \%$ \\
\hline \multicolumn{3}{|c|}{ Jumlah } & 39 & $100 \%$ \\
\hline
\end{tabular}

Melihat hasil belajar peserta didik di atas, peserta didik memliki beberapa kendala atau masalah dalam belajar. Oleh karena itu dilakukan wawancara kepada guru mata pelajaran matematika kelas $X$ SMK Muhammadiyah 3 Metro, dan didapat informasi sebagai berikut:
1. Ketika guru menjelaska bnyak peserta didik yang mengobrol.

2. Banyak peserta didik yang tidak mau mengerjakan tugas.

3. Kurangnya antusias peserta didik terhadap pelajaran matematika karena rendahnya kemampuan dalam perhitungan. 
4. Peserta didik merasa pelajaran matematika sulit, karena banyaknya rumus yang sulit untuk dimengerti.

Sugiyono (2014:407) menyatakan bahwa "Penelitian dan pengembangan atau dalam bahasa inggrisnya Research and Development adalah metode penelitian yang digunakan untuk menghasilkan produk tertentu, dan menguji keefektifan produk tersebut". sedangkan menurut Putra (2013:67) menyatakan bahwa: Secara sederhana $R \& D$ bisa didefinisikan sebagai metode penelitian secara sengaja, sistematis, bertujuan/diarahkan untuk mencaritemukan, merumuskan, memperbaiki, mengembangkan, menghasilkan, menguji keefektifan produk, mode, metode/strategi/cara, jasa, prosedur tertentu yang lebih unggul, baru, efektif, efisien, produktif, dan bermakna.

Mengembangkan bahan ajar yang paling penting adalah harus memperhatikan tingkat penalaran peserta didik, khususnya pada jenjang sekolah menengah kejuruan, kebanyakan dari peserta didik masih berfikir secara konkrit. Kesulitan yang dialami peserta didik dalam pembelajaran matematika salah satunya karena ruang lingkup materi matematika yang terpisah dari kehidupan nyata yang dialami oleh peserta didik. Peserta didik, khususnya yang berkemampuan lambat, membutuhkan pembelajaran yang menyajikan konsep matematika secara bermakna. Yaumi (2013: 245) menyatakan bahwa: Secara teknis, bahan pembelajaran dapat didesain sebagai representasi penjelasan guru, dosen, atau instruktur di depan kelas di samping berperan sebagai pedoman kegiatan pembelajaran termasuk target dan sasaran yang hendak dicapai. Keterangan, uraian, dan pesan seharusnya disampaikan dan informasi yang hendak disajikan dapat dihimpun melalui bahan pembelajaran. Dengan demikian, guru dapat mengefisienkan waktu memberikan penjelasan, dan pada saat yang sama dapat memaksimalkan peningkatan keterampilan sekaligus memiliki banyak waktu untuk membimbing dan membelajarkan peserta didik

$$
\text { Pembelajaran dengan }
$$
menggunakan bahan ajar berbasis pendidikan matematika realistik diharapkan menjadi solusi untuk mengatasi permasalahan tersebut. Pendekatan pendidikan matematika realistik menempatkan matematika pada kehidupan sehari-hari, cerita rekaan atau 
fantasi, atau juga masalah matematika secara langsung. Pendekatan ini diharapkan menjadikan pembelajaran matematika akan menjadi lebih bermakna bagi peserta didik.

Pengembangan dan pemberdayaan pendidik dan tenaga kependidikan (PPPPTK) (2010:7) menyatakan bahwa "pendidikan matematika realistik Indonesia merupakan suatu pendekatan pembelajaran matematika yang mengungkapkan pengalaman dan kejadian yang dekat dengan siswa sebagai sarana untuk memahamkan persoalan matematika". Sedangkan Wijaya (2012) Banyak pihak yang mengganggap pembelajaran matematika realistik harus menggunakan kehidupan seharihari yang dialami oleh peserta didik, padahal kata "realistik" yang berasal dari bahasa belanda "Zich realiseren" yang berarti "untuk dibayangkan". Jadi kata "realistik" tersebut tidak hanya sekedar menggunakan dunia nyata yang dialami peserta didik, tetapi lebih terfokus pada pendidikan matematika realistik dalam pengunaan suatu situasi yang bisa dibayangkan oleh peserta didik.

Materi program linear merupakan materi yang sesuai jika menggunakan pendekatan matematika realistik, karena pada materi program linear banyak digunakan dalam kehidupan sehari-hari, diantaranya dalam bidang arsitektur, industri, kesehatan, dan masih banyak lagi.

Keberadaan bahan ajar sangat berpengaruh terhadap hasil belajar peserta didik, bahan ajar yang bagus dan sesuai dengan kebutuhan akan sangat membantu terhadap hasil belajar peserta didik. Hamalik (dalam kunandar, 2013:62) menyatakan bahwa "hasil belajar adalah pola-pola perbuatan, nilai-nilai, pengertianpengertian dari sikap-sikap serta kemampuan peserta didik". Sedangkan Sudjana, (dalam Kunandar, 2013:62) menjelaskan bahwa "hasil belajar adalah kemampuan-kemampuan yang dimiliki peserta didik setelah menerima pengalaman belajarnya".

Berdasarkan uraian di atas, maka yang menjadi permasalahan dari penelitian ini adalah "Bagaimana mengembangkan bahan ajar berbasis pendidikan matematika realistik pada materi program linear yang layak sesuai dengan kebutuhan peserta didik?", manakah yang lebih efektif terhadap hasil belajar antara penggunaan bahan ajar berbasis pendidikan matematika realistik 
dengan pembelajaran yang menggunakan bahan ajar konvensional pada materi program linear untuk SMK kelas X?".

Berdasarkan permasalahan di atas, maka tujuan penelitian ini adalah menghasilkan produk berupa bahan ajar berbasis pendidikan matematika realistik pada materi program linear yang layak digunakan sesuai kebutuhan peserta didik, dan untuk mengetahui keefektifan bahan ajar berbasis pendidikan matematika realistik pada materi program linear SMK kelas X terhadap hasil belajar.

\section{METODE PENELITIAN}

Penelitian

menggunakan

pengembangan (2014:409) yaitu dengan tahap menggali potensi dan masalah, pengumpulan data, desain produk, validasi desain, revisi desain, uji coba produk, revisi produk, uji coba pemakaian, revisi produk, dan produksi masal. Penelitian yang dilakukan bersifat kualitatif (saran dari validator dan peserta didik) dan kuantitatif (persentase kelayakan dan hasil belajar). Data kualitatif digunakan sebagai acuan untuk dilakukan revisi pada bahan ajar sedangkan persentase kelayakan menggunakan rumus persentase, dan hasil belajar menggunakan statistic inferensial (uji-t). Penelitian dilaksanakan menggunakan dua teknik yaitu angket dan tes. Angket digunakan untuk menilai bahan ajar yang diberikan kepada validator berjumlah 37 item, sedangkan angket yang diberikan kepada peserta didik dalam kelompok kecil dan kelompok besar berjumlah 20 item. Validator yang memberikan penilaian bahan ajar terdiri dari 3 validator, yaitu 1 dosen Pendidikan Matematika Universitas Muhammadiyah Metro, dan 2 orang guru SMA/SMK. Uji coba kelompok kecil dilakukan oleh 5 peserta didik di luar dari kelas eksperimen dan kelas kontrol. Sedangkan uji kelompok besar dilakukan oleh peserta didik kelas X Farmasi 1 (kelas eksperimen) dan sebagai pembandingnya yaitu kelas $\mathrm{X}$ Farmasi 2 (kelas kontrol). Pada uji kelompok besar ini menggunakan desain eksperimen semu (Quasy Exsperimental Design) dengan bentuk desain Posttest-Only Design. Tes digunakan untuk mengetahui keefektifan bahan ajar, bentuk soal yang digunakan adalah bentuk essay, sebanyak 5 soal.

Proses pembelajaran dengan menggunakan bahan ajar berbasis pendidikan matematika 
realistik dilaksanakan di kelas $\mathrm{X}$ Farmasi 1 sedangkan pada kelas X Farmasi 2 diterapkan pembelajaran dengan menggunakan metode konvensional. Kegiatan pembelajaran dilakukan selama 3 kali pertemuan dan satu kali tes hasil belajar. Dalam pembelajaran, dilaksanakan oleh guru dan peserta didik seperti biasanya, bedanya hanya pada penggunaan bahan ajar. Waktu penelitian pada semester genap tahun pelajaran 2015/2016 dengan kurikulum KTSP.

Metode pengumpulan data yaitu dengan angket dan tes. Data tes digunakan untuk melihat keefektifan bahan ajar. jenis tes yang digunakan adalah tes tertulis berbentuk uraian. Untuk mendapatkan data yang akurat, maka soal tes perlu di uji validitas dan reliabilitasnya. Hasil uji validitas dinyatakan valid, dan hasil uji reliabilitas sebesar 0,679 dan mempunyai kriteria tinggi.
Analisis data pada penelitian ini adalah menggunakan rumus persentase untuk mengetahui kelayakan bahan ajar, dan untuk menguji keefektifan bahan ajar digunakan rumus uji-t. Rumus uji-t digunakan setelah data melalui uji normalitas dan uji homogenitas.

\section{HASIL PENELITIAN DAN PEMBAHASAN}

Bahan ajar yang berbentuk prototype 1 diberikan kepada para ahli. Pada tahap ini menggunakan 3 ahli, yaitu satu orang dosen Pendidikan Matematika Universitas Muhammadiyah Metro dan dua orang guru matematika SMA/SMK. Uji pakar ini bertujuan untuk mencari nilai dalam persentase yang akan diinterprestasikan ke dalam kategori kelayakan. Data validasi desain oleh para ahli disajikan dalam Tabel 2 berikut:

Tabel 2. Data hasil validasi desain

\begin{tabular}{|c|l|c|c|}
\hline No & \multicolumn{1}{|c|}{ Item } & Persentase & Keterangan \\
\hline 1 & $\begin{array}{l}\text { Bahan ajar berbasis matematika realistik pada } \\
\text { pembelajaran matematika adalah suatu } \\
\text { pengembangan bahan ajar yang kreatif dan inovatif. }\end{array}$ & $93 \%$ & Sangat Kreatif \\
\hline 2 & $\begin{array}{l}\text { Bahan ajar ini menggunakan bahasa yang baik dan } \\
\text { benar serta mudah untuk dipahami. }\end{array}$ & $93 \%$ & Sangat Mudah \\
\hline 3 & $\begin{array}{l}\text { Memiliki keunggulan dibanding dengan bahan ajar } \\
\text { lain ataupun dengan cara metode konvensional. }\end{array}$ & $87 \%$ & Sangat Unggul \\
\hline 4 & $\begin{array}{l}\text { Bahan ajar ini bisa menjadikan peserta didik } \\
\text { gembira dalam belajar. }\end{array}$ & $73 \%$ & Gembira \\
\hline
\end{tabular}

30| Aksioma

Jurnal Pendidikan Matematika FKIP Univ. Muhammadiyah Metro 


\begin{tabular}{|c|c|c|c|}
\hline 5 & $\begin{array}{l}\text { Penggunaan bahasa dalam bahan ajar ini sesuai } \\
\text { dengan tingkat perkembangan sosial emosional } \\
\text { peserta didik. }\end{array}$ & $73 \%$ & Sesuai \\
\hline 6 & Bahan ajar ini memiliki kejelasan informasi & $73 \%$ & Jelas \\
\hline 7 & Bahan ajar ini memiliki bahasa yang lugas. & $73 \%$ & Lugas \\
\hline 8 & $\begin{array}{l}\text { Pesan yang disampaikan bahan ajar ini memiliki } \\
\text { keterbacaan. }\end{array}$ & $80 \%$ & Terbacaa \\
\hline 9 & Bahan ajar ini memiliki ketetapan kaidah bahasa. & $73 \%$ & Tetap \\
\hline 10 & $\begin{array}{l}\text { Bahan ajar ini memiliki keruntutan dan keterpaduan } \\
\text { antar paragraf. }\end{array}$ & $80 \%$ & Runtut \\
\hline 11 & $\begin{array}{l}\text { Bahan ajar ini menggunakan kalimat yang efektif } \\
\text { dan efisien. }\end{array}$ & $87 \%$ & Sangat Efektif \\
\hline 12 & $\begin{array}{l}\text { Penampilan unsur tata letak pada cover, belakang } \\
\text { dan punggung secara harmonis sesuai irama dan } \\
\text { kesatuan serta konsisten. }\end{array}$ & $80 \%$ & Sesuai \\
\hline 13 & $\begin{array}{l}\text { Penggunaan font (jenis dan ukuran) pada bahan ajar } \\
\text { ini. }\end{array}$ & $73 \%$ & Baik \\
\hline 14 & $\begin{array}{l}\text { Ilustrasi cover bahan ajar menggambarkan } \\
\text { isi/materi ajar. }\end{array}$ & $67 \%$ & Sesuai \\
\hline 15 & $\begin{array}{l}\text { Ilustrasi isi kreatif dan dinamis dan mampu } \\
\text { menangkap makna/arti dari objek. }\end{array}$ & $73 \%$ & Mampu \\
\hline 16 & $\begin{array}{l}\text { Simbol-simbol matematika dalam bahan ajar ini } \\
\text { dapat terbaca jelas oleh peserta didik. }\end{array}$ & $87 \%$ & Sangat Jelas \\
\hline 17 & $\begin{array}{l}\text { Adanya gambar, peserta didik dapat mengingat } \\
\text { informasi yang dipelajari. }\end{array}$ & $80 \%$ & mengingat \\
\hline 18 & $\begin{array}{l}\text { Gambar dalam bahan ajar ini mempermudah guru } \\
\text { menyampaikan materi. }\end{array}$ & $80 \%$ & Mudah \\
\hline 19 & $\begin{array}{l}\text { Desain bahan ajar ini dapat memotivasi semangat } \\
\text { belajar peserta didik. }\end{array}$ & $73 \%$ & Memotivasi \\
\hline 20 & Gambar yang disediakan untuk memperjelas materi. & $87 \%$ & Sangat Jelas \\
\hline 21 & $\begin{array}{l}\text { Ilustrasi yang digunakan dalam desain bahan ajar } \\
\text { sesuai dengan materi. }\end{array}$ & $87 \%$ & Sangat Sesuai \\
\hline 22 & $\begin{array}{l}\text { Desain bahan ajar efektif dan efisien serta tepat } \\
\text { guna dalam mengilustrasikan keseluruhan materi. }\end{array}$ & $80 \%$ & Baik \\
\hline 23 & Kesesuaian dengan SK, KD, dan indikator. & $87 \%$ & Sangat Sesuai \\
\hline 24 & Kesesuaian dengan kebutuhan peserta didik. & $87 \%$ & Sangat Sesuai \\
\hline 25 & Kebenaran substansi materi. & $80 \%$ & Benar \\
\hline 26 & Manfaat untuk menambah wawasan. & $87 \%$ & $\begin{array}{c}\text { Sangat } \\
\text { Bermanfaat }\end{array}$ \\
\hline 27 & $\begin{array}{l}\text { Bahan ajar ini memiliki kejelasan tujuan } \\
\text { pembelajaran. }\end{array}$ & $87 \%$ & Sangat Jelas \\
\hline 28 & $\begin{array}{l}\text { Sistematika penyajian bahan ajar ini sesuai dengan } \\
\text { sistematika penyusunan bahan ajar. }\end{array}$ & $73 \%$ & Sesuai \\
\hline 29 & Penyajian bahan ajar ini disampaikan secara runtut. & $80 \%$ & Runtut \\
\hline 30 & $\begin{array}{l}\text { Bahan ajar ini memuat contoh soal, soal latihan, } \\
\text { dan rangkuman. }\end{array}$ & $80 \%$ & Memuat \\
\hline 31 & Bahan ajar membuat aktif peserta didik. & $80 \%$ & Aktif \\
\hline 32 & $\begin{array}{l}\text { Bahan ajar ini dapat menumbuhkan berpikir kritis, } \\
\text { kreatif, dan inovatif. }\end{array}$ & $80 \%$ & $\begin{array}{l}\text { Menumbuh- } \\
\text { kan }\end{array}$ \\
\hline
\end{tabular}




\begin{tabular}{|c|l|c|c|}
\hline 33 & Bahan ajar ini memiliki kelengkapan informasi. & $80 \%$ & Lengkap \\
\hline 34 & $\begin{array}{l}\text { Penggunaan pendekatan pendidikan matematika } \\
\text { reaistik pada bahan ajar. }\end{array}$ & $73 \%$ & Baik \\
\hline 35 & Penggunaan kreasi bahan ajar. & $87 \%$ & Sangat Baik \\
\hline 36 & Bahan ajar yang interaktif. & $87 \%$ & $\begin{array}{c}\text { Sangat } \\
\text { Interaktif }\end{array}$ \\
\hline 37 & $\begin{array}{l}\text { Saling keterkaitan (intertwitement) antara aspek } \\
\text { atau unit matemtika. }\end{array}$ & $87 \%$ & Sangat Terkait \\
\hline
\end{tabular}

Berdasarkan nilai

persentase setiap item dari penilaian para ahli di atas, kemudian dihitung menunjukkan rata-rata penilaian terhadap bahan ajar sebesar $80,72 \%$ dan masuk dalam kriteria sangat layak. Selain penilaian, juga terdapat saransaran dari para ahli sebagai pedoman revisi. Saran-saran dari validator disajkan dalam Tabel 3 berikut:

Tabel 3. Komentar dan saran para ahli

\begin{tabular}{|c|cl|}
\hline Validator & \multicolumn{1}{c|}{ Komentar } \\
\hline Ahli 1 & - & Perlu ditambahkan halaman francis dan penutup. \\
& - & Perlu ditambahkan tingkat penguasaan pada setiap akhir uji kompetensi. \\
& - & Setiap gambar diberi sumber. \\
& - & Perbaiki kata-kata yang masih salah. \\
& - & Pada masalah nilai optimum perlu ditambahkan ilustrasi dan contoh. \\
\hline Ahli 2 & - & Sebaiknya ganti gambar cover. \\
\hline Ahli 3 3 & - & $\begin{array}{l}\text { Dari awal pembelajaran harus ada kesepakatan tentang daerah himpunan } \\
\text { penyelesaian, daerah yang diarsir atau daerah yang kosong yang menjadi } \\
\end{array}$ \\
& $-\begin{array}{l}\text { Baerah penyelesaian. } \\
\text { Belum ada materi yang menyuguhkan tentang cara menentukan sistem } \\
\text { pertidaksamaan dari sebuah gambar sistem pertidaksamaan linear. }\end{array}$ \\
\hline
\end{tabular}

Berdasarkan Tabel 3 di atas menunjukkan bahwa pada bahan ajar yang berbentuk prototype 1 masih terdapat banyak kekurangan-kekurangan yang harus diperbaiki. Oleh karena itu sebagai dasar dilakukan revisi terhadap bahan ajar adalah komentar dan saran dari para ahli tersebut. Setelah dilakukan revisi, dan para ahli sudah menyatakan layak, selanjutnya bahan ajar yang berbentuk prototype 2 akan diuji cobakan kepada peserta didik dalam kelompok kecil. Uji coba kelompok kecil ini bertujuan untuk mencari nilai dalam persentase yang akan diinterprestasikan ke dalam kategori kelayakan. Data penilaian oleh peserta didik dalam kelompok kecil disajikan dalam Tabel 4. 
Tabel 4. Data penilaian oleh peserta didik dalam kelompok kecil

\begin{tabular}{|c|c|c|c|}
\hline No & Item & Persentase & Keterangan \\
\hline 1 & $\begin{array}{l}\text { Bahan ajar ini menggunakan bahasa yang mudah } \\
\text { untuk dipahami. }\end{array}$ & $80 \%$ & Mudah \\
\hline 2 & $\begin{array}{l}\text { Bahan ajar ini lebih menarik dibandingkan } \\
\text { dengan buku yang biasa digunakan dalam } \\
\text { pembelajaran. }\end{array}$ & $76 \%$ & Menarik \\
\hline 3 & $\begin{array}{l}\text { Bahan ajar ini bisa menjadikan peserta didik } \\
\text { gembira dalam belajar. }\end{array}$ & $60 \%$ & $\begin{array}{l}\text { Cukup } \\
\text { Gembira }\end{array}$ \\
\hline 4 & $\begin{array}{l}\text { Bahan ajar ini dapat memberikan informasi yang } \\
\text { jelas. }\end{array}$ & $76 \%$ & Jelas \\
\hline 5 & $\begin{array}{l}\text { Penampilan unsur tata letak pada cover (sampul } \\
\text { depan) }\end{array}$ & $72 \%$ & Baik \\
\hline 6 & $\begin{array}{l}\text { Jenis dan ukuran huruf, gambar persamaan } \\
\text { (equations) sesuai dan cukup terlihat jelas. }\end{array}$ & $84 \%$ & Sangat Jelas \\
\hline 7 & $\begin{array}{l}\text { Gambar pada cover bahan ajar menggambarkan } \\
\text { isi atau materi ajar. }\end{array}$ & $80 \%$ & Sesuai \\
\hline 8 & $\begin{array}{l}\text { Simbol-simbol matematika dalam bahan ajar ini } \\
\text { dapat terbaca dengan jelas oleh peserta didik. }\end{array}$ & $76 \%$ & Jelas \\
\hline 9 & $\begin{array}{l}\text { Adanya gambar, peserta didik dapat mengingat } \\
\text { informasi yang dipelajari. }\end{array}$ & $72 \%$ & Mengingat \\
\hline 10 & $\begin{array}{l}\text { Desain bahan ajar ini dapat membangunkan } \\
\text { semangat belajar pada peserta didik. }\end{array}$ & $76 \%$ & Semangat \\
\hline 11 & $\begin{array}{l}\text { Gambar yang disediakan dapat memperjelas } \\
\text { materi }\end{array}$ & $80 \%$ & Memperjelas \\
\hline 12 & Tampilan bahan ajar secara keseluruhan menarik. & $72 \%$ & Menarik \\
\hline 13 & $\begin{array}{l}\text { Bahan ajar ini bermanfaat untuk menambah } \\
\text { wawasan. }\end{array}$ & $76 \%$ & Bermanfaat \\
\hline 14 & $\begin{array}{l}\text { Kejelasan uraian materi pembelajaran pada bahan } \\
\text { ajar. }\end{array}$ & $72 \%$ & Jelas \\
\hline 15 & $\begin{array}{l}\text { Peserta didik dapat dengan mudah membaca } \\
\text { daerah himpuan penyelesaian pada grafik yang } \\
\text { ada pada bahan ajar }\end{array}$ & $68 \%$ & Mudah \\
\hline 16 & $\begin{array}{l}\text { Contoh-contoh yang diberikan bermanfaat untuk } \\
\text { peserta didik dalam memahami materi. }\end{array}$ & $76 \%$ & Bermanfaat \\
\hline 17 & $\begin{array}{l}\text { Peserta didik dapat dengan mudah memahami } \\
\text { materi dan contoh yang diberikan }\end{array}$ & $68 \%$ & Mudah \\
\hline 18 & $\begin{array}{l}\text { Setelah mempelajari bahan ajar, peserta didik } \\
\text { dengan baik dapat menyelesaikan sistem } \\
\text { pertidaksamaan linear. }\end{array}$ & $76 \%$ & Baik \\
\hline 19 & $\begin{array}{l}\text { Setelah mempelajari bahan ajar, peserta didik } \\
\text { dengan baik dapat membuat model matematika } \\
\text { dari masalah program linear. }\end{array}$ & $84 \%$ & Sangat Baik \\
\hline 20 & $\begin{array}{l}\text { Setelah mempelajari bahan ajar, peserta didik } \\
\text { dengan baik dapat menentukan nilai optimum } \\
\text { suatu program linear. }\end{array}$ & $72 \%$ & Baik \\
\hline
\end{tabular}




\begin{tabular}{|c|c|}
\hline Berdasarkan & kriteria layak. Selain penilaian, \\
\hline rsentase setiap item dari & saran-saran dari \\
\hline enilaian peserta didik dalam & peserta didik dalam kelompok \\
\hline elompok kecil di atas, kemudian & kecil sebagai pedoman revisi. \\
\hline $\begin{array}{l}\text { lihitung menunjukkan rata-rata } \\
\text { enilaian terhadap bahan ajar }\end{array}$ & $\begin{array}{l}\text { Saran-saran peserta didik tersebut } \\
\text { disajikan dalam Tabel } 5 \text { berikut: }\end{array}$ \\
\hline
\end{tabular}
sebesar $69 \%$ dan masuk dalam

Tabel 5. Komentar dan saran dari peserta didik dalam kelompok kecil.

\begin{tabular}{|l|l|}
\hline \multicolumn{1}{|c|}{ Nama } & \multicolumn{1}{c|}{ Komentar } \\
\hline Ajeng Indriani & -\begin{tabular}{l}
\multicolumn{1}{c|}{ Bahan ajar lebih baik dari yang biasa digunakan dalam } \\
pembelajaran. \\
Bahasa yang digunakan lebih menarik dan mudah \\
dipahami.
\end{tabular} \\
\hline Erlin Arlistia Nanda & $-\begin{array}{l}\text { Bahan ajar sudah bagus, namun harus lebih diperhatikan } \\
\text { dalam kata-katanya }\end{array}$ \\
\hline Maharani Chairunnisa & $-\begin{array}{l}\text { Bahan ajar ini sudah baik, tetapi ada beberapa kata di } \\
\text { dalamnya sulit untuk dipahami, mohon untuk diperbaiki } \\
\text { lagi dalam penulisannya. }\end{array}$ \\
\hline Marcella Putri Utami & $-\begin{array}{l}\text { Penulisan bahan ajar ini sudah cukup baik. Penulisan } \\
\text { kata-katanya harus lebih teliti lagi. }\end{array}$ \\
\hline Marchelinda Dwi Putri & $-\begin{array}{l}\text { Bahan ajar sudah cukup baik dan menarik, dan dapat lebih } \\
\text { mudah dipahami, namun dari segi pengetikannya } \\
\text { alangkah lebih baik bila dikerjakan dengan seksama, agar } \\
\text { mendapat hasil yang memuaskan. }\end{array}$ \\
\hline
\end{tabular}

Berdasarkan Tabel 5 di atas menunjukkan bahwa pada bahan ajar yang berbentuk prototype 2 masih terdapat banyak kekurangan-kekurangan yang harus diperbaiki. Semua peserta didik dalam kelompok kecil menilai bahwa bahan ajar masih perlu diperbaiki dalam segi penulisan atau pengetikan karena masih terdapat kata-kata yang masih salah. Oleh karena itu sebagai dasar dilakukan revisi terhadap bahan ajar adalah komentar dan saran dari peserta didik tersebut. Setelah dilakukan revisi, dan peserta didik sudah menyatakan layak, selanjutnya bahan ajar yang berbentuk prototype 3 akan diuji cobakan kepada peserta didik dalam kelompok besar. Uji coba 
kelompok besar ini bertujuan untuk mencari keefektivan bahan ajar menggunakan hasil belajar peserta didik dan juga untuk mencari nilai dalam persentase yang akan diinterprestasikan ke dalam kategori kelayakan. Data tes hasil belajar disajikan dalam Tabel 6.

Tabel 6. Data tes hasil belajar

\begin{tabular}{|c|c|c|c|}
\hline Kelas & Nilai Maksimum & Nilai Minimum & Rata-rata \\
\hline Eksperimen & 100 & 50 & 76,89 \\
\hline Kontrol & 87 & 45 & 66,46 \\
\hline
\end{tabular}

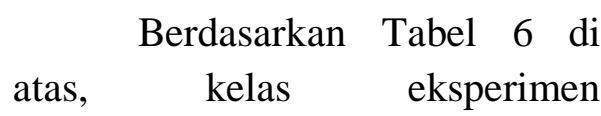
memperoleh minimum 50 dan kelas kontrol memperoleh nilai minimum 45. Nilai maksimum pada kelas eksperimen adalah 100 sedangkan nilai maksimum untuk kelas kontrol adalah 87 . Nilai ratarata yang diperoleh kelas eksperimen adalah 76,89 dan kelas rata-rata kelas kontrol 66,46. Berdasarkan deskripsi dan analisis data yang dilakukan terhadap nilai tes akhir, diketahui bahwa tes akhir matematika peserta didik kelas eksperimen lebih tinggi daripada kelas kontrol.

Sebelum dilakukan pengujian untuk mengetahui keefektifan bahan ajar dengan tes, maka terlebih dahulu uji normalitas dan uji homogenitas. Hasil uji normalitas pada kelas eksperimen untuk $n=39$ dan $a=0,05$, diperoleh $L_{\text {hitung }}=$
0,101602 dan $L_{\text {tabel }}=$ 0,141874 . Sedangkan pada kelas kontrol untuk $n=39$ dan $a=0,05$, diperoleh $L_{\text {hitung }}=$ 0,094338 dan $L_{\text {tabel }}=$ 0,141874 . Karena pada kedua sampel didapat untuk $L_{\text {hitung }}<$ $L_{\text {tabel }}$, maka $\mathrm{H}_{0}$ diterima artinya sampel berasal dari populasi yang berdistribusi normal. Pada uji homogenitas didapat $\chi^{2}$ hitung $=$ 0,0349419 dengan taraf signifikansi $a=0,05$ serta derajat kebebasan $(\mathrm{dk})=1$ didapat $\chi^{2}$ tabel $=3,8414591$ dengan kata lain $\chi^{2}$ hitung $<\chi_{\text {tabel }}^{2}$ maka $\mathrm{H}_{0}$ diterima yang artinya kedua sampel mempunyai varians yang sama. Langkah selanjutnya yaitu melakukan uji-t. berdasarkan perhitungan hasil uji-t, diperoleh $t_{\text {hitung }}=4,039092$ dan untuk nilai $\mathrm{t}_{\text {Tabel }}$ diperoleh dari Tabel $\mathrm{t}$ dengan taraf signifikan $a=0,05$ yaitu 
sebesar 1,991673. Ini berarti $t_{\text {hitung }}$ $>t_{\text {Tabel}}$, dengan demikian hipotesis $\mathrm{H}_{\mathrm{a}}$ diterima. Sehingga rata-rata hasil belajar peserta didik yang menggunakan bahan ajar berbasis Pendidikan Matematika Realistik (PMR) lebih besar dari rata-rata hasil belajar peserta didik yang menggunakan bahan ajar konvensional pada materi program linear. sehingga dapat dikatakan bahawa bahanajar yang dikembangkan telah dinyatakan efektif yaitu dengan melihat hasil belajar peserta didik dalam kelompok besar. Selain tes, pada uji coba kelompok besar ini juga terdapat penilaian terhadap bahan ajar. Data Penilaian peserta didik dalam kelompok besar disajikan dalam Tabel

Tabel 7. Data penilaian peserta didik dalam kelompok besar

\begin{tabular}{|c|c|c|c|}
\hline No & Item & Persentase & Keterangan \\
\hline 1 & $\begin{array}{l}\text { Bahan ajar ini menggunakan bahasa yang mudah } \\
\text { untuk dipahami. }\end{array}$ & $72,50 \%$ & Mudah \\
\hline 2 & $\begin{array}{l}\text { Bahan ajar ini lebih menarik dibandingkan } \\
\text { dengan buku yang biasa digunakan dalam } \\
\text { pembelajaran. }\end{array}$ & $77,50 \%$ & Menarik \\
\hline 3 & $\begin{array}{l}\text { Bahan ajar ini bisa menjadikan peserta didik } \\
\text { gembira dalam belajar. }\end{array}$ & $77,50 \%$ & Gembira \\
\hline 4 & $\begin{array}{l}\text { Bahan ajar ini dapat memberikan informasi yang } \\
\text { jelas. }\end{array}$ & $80 \%$ & Jelas \\
\hline 5 & $\begin{array}{l}\text { Penampilan unsur tata letak pada cover (sampul } \\
\text { depan) }\end{array}$ & $82,50 \%$ & Sangat Baik \\
\hline 6 & $\begin{array}{l}\text { Jenis dan ukuran huruf, gambar persamaan } \\
\text { (equations) sesuai dan cukup terlihat jelas. }\end{array}$ & $75 \%$ & Jelas \\
\hline 7 & $\begin{array}{l}\text { Gambar pada cover bahan ajar menggambarkan } \\
\text { isi atau materi ajar. }\end{array}$ & $77,50 \%$ & Sesuai \\
\hline 8 & $\begin{array}{l}\text { Simbol-simbol matematika dalam bahan ajar ini } \\
\text { dapat terbaca dengan jelas oleh peserta didik. }\end{array}$ & $80 \%$ & Jelas \\
\hline 9 & $\begin{array}{l}\text { Adanya gambar, peserta didik dapat mengingat } \\
\text { informasi yang dipelajari. }\end{array}$ & $77,50 \%$ & Mengingat \\
\hline 10 & $\begin{array}{l}\text { Desain bahan ajar ini dapat membangunkan } \\
\text { semangat belajar pada peserta didik. }\end{array}$ & $75 \%$ & Semangat \\
\hline 11 & $\begin{array}{l}\text { Gambar yang disediakan dapat memperjelas } \\
\text { materi }\end{array}$ & $80 \%$ & Memperjelas \\
\hline 12 & Tampilan bahan ajar secara keseluruhan menarik. & $75 \%$ & Menarik \\
\hline 13 & $\begin{array}{l}\text { Bahan ajar ini bermanfaat untuk menambah } \\
\text { wawasan. }\end{array}$ & $82,50 \%$ & $\begin{array}{c}\text { Sangat } \\
\text { Bermanfaat }\end{array}$ \\
\hline 14 & $\begin{array}{l}\text { Kejelasan uraian materi pembelajaran pada bahan } \\
\text { ajar. }\end{array}$ & $70 \%$ & Jelas \\
\hline 15 & $\begin{array}{l}\text { Peserta didik dapat dengan mudah membaca } \\
\text { daerah himpuan penyelesaian pada grafik yang } \\
\text { ada pada bahan ajar }\end{array}$ & $77,50 \%$ & Mudah \\
\hline
\end{tabular}

36 | Aksioma

Jurnal Pendidikan Matematika FKIP Univ. Muhammadiyah Metro 


\begin{tabular}{|c|l|c|c|}
\hline 16 & $\begin{array}{l}\text { Contoh-contoh yang diberikan bermanfaat untuk } \\
\text { peserta didik dalam memahami materi. }\end{array}$ & $77,50 \%$ & Bermanfaat \\
\hline 17 & $\begin{array}{l}\text { Peserta didik dapat dengan mudah memahami } \\
\text { materi dan contoh yang diberikan }\end{array}$ & $72,50 \%$ & Mudah \\
\hline 18 & $\begin{array}{l}\text { Setelah mempelajari bahan ajar, peserta didik } \\
\text { dengan baik dapat menyelesaikan sistem } \\
\text { pertidaksamaan linear. }\end{array}$ & $70 \%$ & Baik \\
\hline 19 & $\begin{array}{l}\text { Setelah mempelajari bahan ajar, peserta didik } \\
\text { dengan baik dapat membuat model matematika } \\
\text { dari masalah program linear. }\end{array}$ & $\begin{array}{l}\text { Setelah mempelajari bahan ajar, peserta didik } \\
\text { dengan baik dapat menentukan nilai optimum } \\
\text { suatu program linear. }\end{array}$ & $72,50 \%$ \\
\hline
\end{tabular}

Berdasarkan nilai persentase setiap item dari penilaian peserta didik dalam kelompok besar di atas, kemudian dihitung menunjukkan rata-rata penilaian terhadap bahan ajar sebesar $77 \%$ dan masuk dalam kriteria layak. Selain penilaian, juga terdapat saran-saran dari peserta didik dalam kelompok besar sebagai pedoman revisi. Saran-saran peserta didik tersebut disajikan dalam Tabel 8 berikut:

Tabel 8. Komentar dan saran dari peserta didik dalam kelompok besar

\begin{tabular}{|c|c|}
\hline Kelompok & Komentar \\
\hline 1 & $\begin{array}{ll}\text { - } & \text { Bahan ajar ini sangat membantu kami. } \\
\text { - } & \text { Contoh soal yang diberikan sangat membantu dalam memahami materi. }\end{array}$ \\
\hline 2 & $\begin{array}{l}\text { - Bahan ajar ini sudah bagus, ditambah dengan adanya soal ujian nasional } \\
\text { membuat kami bersemangat dalam belajar. }\end{array}$ \\
\hline 3 & $\begin{array}{l}\text { - } \quad \text { Bahan ajar ini cukup baik dan membantu kami dalam belajar. } \\
\text { - Soal-soal yang diberikan tidak sulit namun membutuhkan pemahaman } \\
\text { dan menantang. }\end{array}$ \\
\hline 4 & $\begin{array}{ll}\text { - } & \text { Bahan ajar sedikit mudah dipahami. } \\
\text { - } & \text { Kami harus teliti agar dapat menjawab soal dengan benar. } \\
\text { - } & \text { Ada kata yang salah halaman } 13 \text { mohon diperbaiki } \\
\end{array}$ \\
\hline 5 & - $\quad$ Bahan ajar ini sudah bagus, terima kasih. \\
\hline 6 & $\begin{array}{l}\text { - Bahan ajar ini cukup membantu, tetapi kami kurang memahami materi } \\
\text { yang telah diberikan. }\end{array}$ \\
\hline 7 & - $\quad$ Sangat membantu, membuat kami semakin ingin meningkatkan belajar. \\
\hline 8 & - $\quad$ Bahan ajar ini membantu kami dalam belajar. \\
\hline
\end{tabular}

Berdasarkan Tabel 8 di atas menunjukkan bahwa pada bahan ajar yang berbentuk prototype 3 masih terdapat kekurangan-kekurangan yang harus diperbaiki. Oleh karena itu 
sebagai dasar dilakukan revisi terhadap bahan ajar adalah komentar dan saran dari peserta didik tersebut. Setelah dilakukan revisi, dan peserta didik sudah menyatakan layak, selanjutnya bahan ajar yang berbentuk prototype 3 ini sudah siap dicatak untuk menjadi bahan ajar yang sesungguhnya.

Berdasarkan deskripsi dan analisis data yang telah dilakukan terhadap penilaian dari para ahli, penilaian peserta didik dalam kelompok kecil, peserta didik dalam kelompok besar, dan juga nilai tes akhir, diketahui bahwa bahan ajar berbasis pendidikan matematika realistik pada materi program linear sudah dinyatakan layak, oleh para ahli dan peserta didik dalam kelompok kecil, juga peserta didik dalam kelompok besar. Sedangkan analisis terhadap hasil belajar peserta didik menunjukkan bahan ajar berbasis pendidikan matematika realistik lebih efektif dibandingkan dengan bahan ajar konvensional. Lebih tingginya hasil belajar peserta didik yang menggunakan bahan ajar berbasis pendidikan matematika realistik karena dalam bahan ajar ini menggunakan pendekatan yang melibatkan kehidupan sehari-hari dalam penggunaan materi, contoh soal, maupun soal-soal sehingga pembelajaran menjadi lebih bermakna. Selain itu pada bahan ajar dilengkapi dengan latihanlatihan berupa soal ujian nasional beberapa tahun terakhir yang menjadikan bahan ajar ini berbeda dari bahan ajar yang ada.

\section{KESIMPULAN DAN SARAN}

Berdasarkan hal di atas dapat disimpulkan bahwa bahan ajar yang dikembangkan telah dinyatakan layak untuk digunakan berdasarkan penilaian dari para ahli dan juga peserta didik, bahan ajar ini efektif dalam pembelajaran berdasarkan rata-rata hasil belajar peserta didik yang menunjukan lebih tinggi dibandingkan rata-rata hasil belajar peserta didik dengan bahan ajar konvensional.

Berdasarkan kesimpulan yang diperoleh selama melaksanakan penelitian dan pengembangan, maka saran pemanfaatan bagi peserta didik adalah bahan ajar ini dapat dimanfaatkan untuk membantu peserta didik dalam meningkatkan hasil belajar. Bagi guru, bahan ajar ini dapat dimanfaatkan dalam pembelajaran dan juga sebagai motivasi guru selalu mengembangkan bahan ajar. Sedangkan saran untuk pengembangan produk lebih lanjut 
adalah bahan ajar yang dikembangkan ini belum sempurna, karena penggunaan bahan ajar ini harus disesuaikan dengan keseharian lingkungan peserta didik. Jika ingin dikembangkan lebih lanjut tentang bahan ajar ini, maka carilah keterkaitan dengan keterbacaan bahan ajar ini terhadap peserta didik, dan pengaruh bahan ajar ini secara spesifik yang ditinjau dari lingkungan yang ada pada peserta didik, karena pendekatan matematika realistik itu sangat erat sekali dengan kehidupan nyata. Hal itu sangat berguna jika ingin meneliti tentang seberapa pengaruhnya bahan ajar ini, karena peserta didiklah yang akan mempelajari.

\section{DAFTAR PUSTAKA}

Kunandar. 2013. Guru Profesional Implementasi Kurikulum Tingkat Satuan Pendidikan (KTSP) dan Sukses dalam Sertifikasi Guru. Jakarta : Rajawali Pers.

PPPPTK. 2010. Pembelajaran Matematika dengan Pendekatan Realistik. Yogyakarta: PPPPTK Matematika.

Putra, Nusa. 2013. Research and Development. Jakarta : Raja Grafindo Persada.
Trianto. 2009. Mendesaian Model Pembelajaran InovatifProgresif. Jakarta: Kencana.

Sanjaya, Wina. 2013. Penelitian Pendidikan Jenis, Metode dan Prosedur. Jakarta: Kencana.

Sugiyono. 2014. Metode Penelitian Pendidikan Pendekatan Kuantitatif, Kualitatif, dan $R \& D$. Bandung : Alfabeta.

Yaumi, Muhammad. 2013. Prinsip-Prinsip Desain Pembelajaran. Jakarta: Kencana. 